\title{
PERFORMANCE OF SOME PROMISING SUGARCANE VARIETIES GROWN UNDER DIFFERENT ROW SPACINGS AND SEED RATES Mahmoud, E.A. ${ }^{1}$; H.H. El.Hennawy'; H. Ferweez ${ }^{2}$ and H.A. Abd El-Fatah ${ }^{2}$ 1- Agron.Dept.Fac.Agric.Cairo Univ. Egypt. \\ 2- Sugar Crops Res. INSt., Agric. Res. Centre, Giza, Egypt.
}

\begin{abstract}
It is imperative to define precisely the optimal plant population of a variety in order to maximize sugar production at minimum cost. This study was carried out during 2005/2006 and 2006/2007 seasoNS at Mallawi Agric. Res., Station, El-Minia Governorate, Egypt, to investigate the changes in growth, yield and juice quality characters of some promising sugarcane varieties, i.e. G.99-103, G.98-28 and Phil.8013, compared to the commercial variety G.T.54-9 at different row spacing; 80 , 100 and $120 \mathrm{~cm}$ and seed rates (9 and $12-$ buds/m long) for plant cane.

The collected data pointed out that, there were significant differences in stalk length, total soluble solids (TSS), sucrose, purity, reducing sugars, sugar recovery percentages, millable cane yield and recoverable sugar yield (ton/fed) with increasing row spacings from 80 to 100 and $120 \mathrm{~cm}$ in the two growing seasons.

Meanwhile, the evaluated sugarcane varieties differed significantly in all studied characters in both seasoNS. Increasing seed rates from 9 to 12-buds/m under the three tested row spacing caused significant difference in stalk length, stalk diameter, and.

Generally it is concluded that, G.99-103 variety planted in $100 \mathrm{~cm}$ row spacing and $12-\mathrm{buds} / \mathrm{m}$ of seed rates $(48,000 \mathrm{buds} / \mathrm{fed})$ are preferable under El-Minia for production sugarcane because it gave the highest values of millable cane (59.53 ton/fed) and recoverable sugar yield (6.28 ton/fed).
\end{abstract}

Keywords: Sugarcane, Plant population, Row spacing, Cane yield

\section{INTRODUCTION}

The aim of the sugarcane breeder and technologist is to produce new varieties which will not only increase the production of sugar per land unit, but also allow of production at a lesser price per ton of the manufactured product. There are, of course, several important attributes in a variety which, individually and severally, subscribe to its commercial value. These include such major factors as yield of canes in the field, sucrose $\%$ in juice and milling quality (SteveNSon, 1965). Mokadem et al. (2000) cleared that the highest sugar recovery percentage was obtained under the $100 \mathrm{~cm}$ row spacing $(13.6 \%)$ followed by $120 \mathrm{~cm}(13.1 \%)$ then $140 \mathrm{~cm}(12.9 \%)$. Shah-Nawaz et al. (2000) showed that sucrose content in cane juice was not affected by spacing and varied from 18.53 to $20.85 \%$, when sugarcane was grown under 90 and $120 \mathrm{~cm}$ row spacing, respectively. In this respect, EL-Geddawy et al. (2002a) concluded that the widest row spacing $(140 \mathrm{~cm})$ gave the highest Brix value, sucrose, purity, and sugar recovery percentages of the second ratoon. The narrowest row spacing $(100 \mathrm{~cm})$ produced the highest reducing sugar 
percentage in the $1^{\text {st }}$ and $2^{\text {nd }}$ ratoon. They added that, $\mathrm{F} 153$ variety grown at a row spacing of $140 \mathrm{~cm}$ gave the highest Brix parentage, sucrose, purity, and sugar recovery percentages. Osman et al. (2004) showed that using $80 \mathrm{~cm}$ row spacing produced the highest value of cane yield, 50.8 ton/fed and sugar yield (6.25 ton/fed). Ismael et al. (2007) studied dual row planting, coNSisting of pairs of cane rows $0.5 \mathrm{~m}$ apart with $1.8 \mathrm{~m}$ between their centers compared to the standard row spacing of $1.6 \mathrm{~m}$. Results showed that the increase in cane yields with dual row planting varied between 3 and $28 \%$ depending on cane variety. They added that no significant difference in sucrose content was observed between the two spacings.

Sukhchain and Saini (1998) showed that there was significant differences among sugarcane cultivars in cane yield. In this subject, Abd Ellatif et al. (1993) evaluated three sugarcane varieties i.e. G.T.54-9, G.85-37 and G.68-88. They noticed that G.85-37 variety recorded the best yields of cane and sugar compared with the other tested varieties. Yousef et al. (2000) evaluated six sugarcane varieties (G.T.54-9, G.85-37, G.84-47, F.153, G.75-368 and G.87-55). Data revealed that sugarcane varieties significantly differed in number of millable cane $/ \mathrm{m}^{2}$, cane length, cane diameter and cane yield. They added that G.85-37 variety gave the tallest millable cane $(285.4 \mathrm{~cm})$, while G.87-55 variety gave the highest values of milable cane diameter. Moreover Abd El-Azez (2008) evaluated six sugarcane varieties; G.T.54-9, G.84-47, G.99-103, G.98-28, G.98-78, and Phil.8013. Data revealed that, sugarcane varieties differed significantly in the number of plants $/ \mathrm{m}^{2}$, stalk length, stalk diameter, number of internodes, single stalk weigh, cane and sugar yields. Phil.8013 and G.99-103 varieties scored the greatest cane yield, whereas; Phil.8013 and G.T.54-9 varieties recorded the highest sugar yield. G.84-47 variety surpassed all tested varieties in quality parameters (TSS, Purity, and sugar recovery \%). In this respect El-Sogheir and Ferweez (2009) evaluated five sugarcane varieties (G.T.54-9, G.84-47, G.99-103, G.98-28, and Phil. 8013). Results cleared that G.84-47 variety surpassed all tested varieties in sucrose, purity, sugar recovery percentages and millable cane yield (ton/fed). G.99-103 variety gave the highest value of stalk length $(\mathrm{cm})$.

Regarding the effect of plant deNSity, Dominf and Plana (1989) showed that planting deNSity had no effect on quality attributes when sugarcane grown under 9,15 or 21 -buds $/ \mathrm{m}^{2}$ in rows 1.5 and $1.6 \mathrm{~m}$ apart. Avtar-Singh and Rajbahadur-Singh (2001) observed that the highest cane yield ( 46 ton/ha) was obtained at a seed rate of 50000 three-budded setts/ha as compared to 75000 three-budded setts/ha. Azazy et al. (2003) evaluated five sugarcane varieties; G.84-48, G.85-37, G.95-21, F.160 and the commercial variety G.T.54-9. They found that growing sugarcane using 1.5drills of cane cuttings significantly produced stalks with thicker diameter as compared with those obtained by planting sugarcane with 2.0-drills of cane cuttings. Tej-Pratap et al. (2006) studied the effect of sowing rates; 44,400 or 66,700 setts per ha. Results showed that quality parameters i.e. extraction percentage, Brix, purity, sucrose content and available sugar did not exhibit significant variatioNS accounted to sowing rates, although marginally higher values were recorded with higher sowing rate $(66,700$ setts per ha). 
The objective of this article was to determine the proper population deNSity to maximize sugar production of some promising sugarcane varieties.

\section{MATERIALS AND METHODS}

Two field experiments were conducted at Mallawi Agric. Res. Station, El-Minia Governorate, Egypt, including two plant cane crops during $2005 / 2006$ and $2006 / 2007$ seasoNS on silty clay loam (the texture of the soil was silty clay with about 1.2 organic matter and $\mathrm{PH}$ was 8.0). Available $\mathrm{N}$ was $21 \mathrm{mg} / \mathrm{kg}$ soil, available $\mathrm{P}$ was $8.5 \mathrm{ppm}$ while available $\mathrm{K}$ was $175 \mathrm{mg} / \mathrm{kg}$ soil) to study the effect of different row spacings and seed rates on productivity and quality characteristics of some promising sugarcane varieties. Two plant cane crops were grown on March 10, 2005 and March 12, 2006 using dry method.

A split-split plot design with four replicates was used where three row spacing; 80,100 and $120 \mathrm{~cm}$ were arranged in the main plots, four sugarcane varieties; G.T.54-9, G.103-99, G.98-28 and Phil.8013 were allocated in the sub plots and two seeding rates; 9 and 12-buds per one meter in length were distributed in the sub-sub plots.

The experimental unit area was $36 \mathrm{~m}^{2}$ which coNSists of 5 rows, $6 \mathrm{~m}$ long and $120 \mathrm{~cm}$ apart or $30 \mathrm{~m}^{2}$ which coNSists of 5 rows, $6 \mathrm{~m}$ long and $100 \mathrm{~cm}$ apart and/or $24 \mathrm{~m}^{2}$ which coNSists of 5 rows, $6 \mathrm{~m}$ long and $80 \mathrm{~cm}$ apart. Each plot area was planted with either 270 buds/plot (9-buds $/ \mathrm{m}$ long) or 360 buds/plot (12-buds/m long). Therefore, six populatioNS were coNStructed [combination of row spacing and number of buds $/ \mathrm{m}$ long];

1) $80 \mathrm{~cm}$ row spacing and 9 -buds $/ \mathrm{m}(45,000 \mathrm{buds} / \mathrm{fed})$.

2) $100 \mathrm{~cm}$ row spacing and 9 -buds/m (36.000 buds/fed).

3) $120 \mathrm{~cm}$ row spacing and $9-\mathrm{buds} / \mathrm{m}(30.000 \mathrm{buds} / \mathrm{fed})$.

4) $80 \mathrm{~cm}$ row spacing and 12 -buds $/ \mathrm{m}(60.000 \mathrm{buds} / \mathrm{fed})$.

5) $100 \mathrm{~cm}$ row spacing and 12 -buds/m (48.000 buds/fed).

6) $120 \mathrm{~cm}$ row spacing and $12-\mathrm{buds} / \mathrm{m}$ (40.000 buds/fed).

Phosphorus fertilizer in the form of calcium super-phosphate $\left(15.5 \% \mathrm{P}_{2} \mathrm{O}_{5}\right)$ fertilizer was used at the rate of $60 \mathrm{~kg} \mathrm{P} \mathrm{P}_{5} / \mathrm{fed}$ broadcasted after ridging and before planting. Potassium as potassium sulphate $\left(48 \% \mathrm{~K}_{2} \mathrm{O}\right)$ was used at the rate of $48 \mathrm{~kg} \mathrm{~K} \mathrm{~K}_{2} \mathrm{O} / \mathrm{fed}$ after two months from sowing. Nitrogen fertilizer as $\mathrm{NH}_{4} \mathrm{NO}_{3}(33.5 \%)$ was added to the soil in two equal doses as side dressing in cane rows (the first one after full emergence of cane plants and the other one month later).

Harvest took place right after 12 months on 14th and 18th of March 2006 and 2007, respectively. Millable stalk counts were recorded by counting the number of mature stalks in each plot after harvest. Stalk population was calculated as the number of millable stalks per feddan.

Data obtained in this work were as follow :

A random 20-stalks hand-harvested sample was taken from each subsub plot and used to determine the following traits:- 
Mahmoud, E.A. et al.

1- vegetative traits

1-1-Stalk length $(\mathbf{c m})$ : It was measured from land surface to the top visible dewlap.

1-2-Stalk diameter (cm): It was measured at the middle part of the stalk.

1-3- Number of millable stalks per feddan: was calculated on plot basis

2- Quality parameters:

The above 20 stalks samples were crushed by passing them three times through a 2-roll electric mill. Juice was used to evaluate the following traits:

2.1. Total soluble solids(TSS \%) was determined using "Brix hydrometer" standardized at $20^{\circ} \mathrm{C}$ as in A.O.A.C. (1995).

2.2. Sucrose \% juice was determined using Sacharemeter according to A.O.A.C. (1995)

2.3. Purity \% juice was calculated according to Singh and Singh (1998) using the following formula: Purity $\%=($ Sucrose $\% \div$ TSS $\%) x$ 100

2.4. Reducing sugars \%juice was determined according to A.O.A.C. (1995)

2.5. Sugar recovery $\%$ was calculated by the following equation according to Yadav and Sharma (1980).

Sugar recovery $\%=\{($ Pol\% $-0.8 /$ Purity\% juice $) \times($ Purity\% juice $-40 / 100-40)\} \times 100$

Pol\% of cane stalks was calculated by the following equation according to Satisha et al. (1996).

Pol \% $=\{$ Brix\% $-($ Brix\%- sucrose $\%) 0.4\} 0.73$.

3- Millable cane and recoverable sugar yields:

3-1- Millable cane yield (ton/fed): Three middle rows of each sub-sub plots were harvested, cleaned and weighed. Cane yield per feddan was calculated.

3-2- Recoverable sugar yield (ton/fed): was estimated according to the following equation:

Recoverable sugar yield $($ ton/fed) $=$ Millable cane yield (ton/fed) $\times$ sugar recovery \%.

Statistical analysis of all data was carried out according to Gomez and Gomez (1984).The differences between meaNS of the different treatments were compared using the least significant difference (LSD) at $5 \%$ level.

\section{RESULTS AND DISCUSSION}

\section{1-Vegetative traits:}

1.1. Stalk length $(\mathrm{cm})$ :

Results in Table 1 illustrated that inter-row spacings differed significantly in their effect on stalk length. The narrowest row spacing $(80 \mathrm{~cm})$ scored the highest value of stalk length $(235.02 \mathrm{~cm})$, while the lowest value $(221.41 \mathrm{~cm})$ resulted from the widest row spacing $(120 \mathrm{~cm})$. These results coincided with those obtained by El-Gergawy et al. (1995), Rizk et al. (2004) and Elwan (2007). 
Results in Table 1 pointed out that significant differences among the studied sugarcane varieties in their stalk length. G.99-103 variety gave the tallest stalks $(245.81 \mathrm{~cm})$, followed by G.T54-9, G.98-28, and Phil.8013 varieties in a descending order. These results might be due to genetic makeup and are in accordance with those reported by El-Sayed (1996), Abo ElGhait (2000) and Abd El-Azez (2008).

Seed rates had a significant effect on stalk length (Table1). Increasing seed rates from 9 to 12 -buds/m increased stalk length from 224.74 to $231.58 \mathrm{~cm}$. This increase could be attributed to the elongation effect of invisible solar radiation which predominates in deNSe planting (Chang 1974). These results are in accordance with these reported by ElGergawy et al. (1995) and Yousef et al. (2000).

High significant interaction effect was found between row spacings and varieties with regard to stalk length. The highest value of stalk length $(251.13 \mathrm{~cm})$ was scored by $\mathrm{G} 99-103$ with $80 \mathrm{~cm}$ row spacing.

Significant interaction was found between varieties and seed rates. The highest value $(248.71 \mathrm{~cm})$ was recorded by G 99-103 variety with 12 buds $/ \mathrm{m}$.

1.2- Stalk diameter (cm):

Results in Table 1 showed that row width had a significant effect on stalk diameter. Row width of $120 \mathrm{~cm}$ attained the highest stalk diameter $(3.10 \mathrm{~cm})$ while, the lowest one $(2.97 \mathrm{~cm})$ was recorded by the rate of $80 \mathrm{~cm}$ row spacing. The increase in stalk diameter under the wider row spacing may be due to low inter plant competition for nutrients, soil moisture and light, coNSequently plants grow much better in wider rows than in the closely spaced ones. Theses results are in good agreement with those obtained by El-Geddawy et al. (2004) and Rizk et al. (2004).

Varieties exhibited significant differences in stalk diameter (Table1). Phil.8013 variety significantly surpassed G.99-103, G.98-28 and G.T.54-9 varieties by $0.01,0.11$ and $0.46 \mathrm{~cm}$, respectively. This result are in agreement with those reported by Nafei (1993) and Osman et al. (2004).

Planting sugarcane varieties with 9 -buds $/ \mathrm{m}$ significantly increased stalk diameter $(3.08 \mathrm{~cm})$ as compared with 12 -buds $/ \mathrm{m}(2.99 \mathrm{~cm})$. Theses findings are in agreement with El-Gergawi et al. (1995) and El-Shafai (1996).

All interactions among the studied factors were insignificant effect except the second order interaction, where Phil.8013 variety under 120 $\mathrm{cm}$ rows spacing and $9-\mathrm{buds} / \mathrm{m}$ (30.000 buds/fed) gave the thickest stalks $(3.30 \mathrm{~cm})$.

\section{3- Number of millable stalks per feddan}

Results in Table 1 showed that differences in number of millable stalks/fed between row spacings were significant. Results revealed that decreasing row spacing significantly increased number of millable stalks/fed. $80 \mathrm{~cm}$ row spacing surpassed 100 and $120 \mathrm{~cm}$ by 9.52 and 22.74 thousand stalks/fed, respectively. Similar findings were reported by Osman et al. (2004) and Elwan (2007).

Varieties differed significantly in number of millable stalks/fed (Table1). The highest number of millable stalks (49.93 thousand/fed) was obtained 
from G.103-99 variety, whereas the lowest value of this trait (42.56 thousand/fed) resulted from Phil.8013 variety. Other varieties ranked in between, reflecting the tillering capacity of the different varieties. These findings are in coincidence with those obtained by El-Sogheir and Mohamed (2003).

Increasing seed rate form 9 to 12 -buds $/ \mathrm{m}$ significantly increased number of millable stalks from 43.44 to 50.48 thousand stalks/fed. Similar results were reported by EL-Sayed (1996) and Usman (1989).

The interaction between row spacings and seed rates was significant. Plating sugarcane on the narrowest row spacing $(80 \mathrm{~cm})$ with $12-\mathrm{buds} / \mathrm{m}$ $(60,000$ buds/fed) gave the highest number of millable stalks (63.70 thousand/fed), whereas the lowest value (33.82 thousand/fed) was resulted from $120 \mathrm{~cm}$ row distance with $9-\mathrm{buds} / \mathrm{m}$ (30,000 buds/fed).

Table (1): Effect of row spacings, varieties and seed rates on stalk length $(\mathrm{cm})$, stalk diameter $(\mathrm{mm})$ and number of millable stalks $\left(10^{3} / \mathrm{fed}\right)$ of plant cane crops during $2005 / 06$ and 2006/07 (combined analysis of the two seasoNS).

\begin{tabular}{|c|c|c|c|c|c|c|c|c|c|c|}
\hline \multirow{2}{*}{$\begin{array}{l}\text { Row } \\
\text { spacings } \\
\text { (A) }\end{array}$} & \multirow{2}{*}{$\begin{array}{l}\text { Varieties } \\
\text { ( B ) }\end{array}$} & \multicolumn{2}{|c|}{$\begin{array}{l}\text { Stalk length } \\
\text { Seed rates ( C ) }\end{array}$} & \multicolumn{4}{|c|}{$\begin{array}{l}\text { Stalk diameter } \\
\text { Seed rates ( C ) }\end{array}$} & \multicolumn{3}{|c|}{$\begin{array}{l}\text { N. of millable stalks } \\
10^{3} / \text { fed } \\
\text { Seed rates ( C ) }\end{array}$} \\
\hline & & $\begin{array}{c}\text { 9- } \\
\text { buds/m }\end{array}$ & $\begin{array}{l}12- \\
\text { buds/m }\end{array}$ & Mean & $\begin{array}{c}\text { 9- } \\
\text { buds/m }\end{array}$ & $\begin{array}{c}12- \\
\text { buds/m }\end{array}$ & Mean & $\begin{array}{c}9- \\
\text { buds/m }\end{array}$ & $\begin{array}{c}12- \\
\text { buds/m }\end{array}$ & Mean \\
\hline \multirow{4}{*}{$120 \mathrm{~cm}$} & Phil.8013 & 198.8 & 202.6 & 200.7 & 3.30 & 3.18 & 3.24 & 30.18 & 34.07 & 32.12 \\
\hline & G.T.54-9 & 231.8 & 237.2 & 234.5 & 2.89 & 2.73 & 2.81 & 34.72 & 39.16 & 36.94 \\
\hline & G.98-28 & 204.0 & 221.6 & 212.8 & 3.15 & 3.08 & 3.11 & 33.48 & 39.24 & 36.36 \\
\hline & G.99-103 & 235.7 & 239.2 & 237.5 & 3.29 & 3.21 & 3.25 & 36.89 & 41.89 & 39.39 \\
\hline \multirow[t]{2}{*}{ Mean } & & 217.6 & 225.1 & 221.4 & 3.16 & 3.05 & 3.10 & 33.82 & 38.59 & 36.21 \\
\hline & Phil.8013 & 213.0 & 219.6 & 216.3 & 3.25 & 3.13 & 3.19 & 38.91 & 43.44 & 41.18 \\
\hline \multirow{3}{*}{$100 \mathrm{~cm}$} & G.T.54-9 & 236.8 & 243.5 & 240.1 & 2.77 & 2.66 & 2.72 & 43.36 & 51.13 & 47.25 \\
\hline & G.98-28 & 203.0 & 210.8 & 206.9 & 3.12 & 3.00 & 3.06 & 42.53 & 50.11 & 46.32 \\
\hline & G.99-103 & 245.0 & 252.6 & 248.8 & 3.13 & 3.17 & 3.15 & 44.43 & 51.96 & 48.19 \\
\hline \multirow[t]{2}{*}{ Mean } & & 224.4 & 231.6 & 228.0 & 3.07 & 2.99 & 3.03 & 42.31 & 49.16 & 45.73 \\
\hline & Phil.8013 & 221.1 & 224.0 & 222.5 & 3.13 & 3.07 & 3.10 & 50.52 & 58.26 & 54.39 \\
\hline \multirow{3}{*}{$80 \mathrm{~cm}$} & G.T.54-9 & 241.8 & 249.0 & 245.4 & 2.65 & 2.63 & 2.64 & 55.76 & 64.55 & 60.16 \\
\hline & G.98-28 & 217.5 & 224.3 & 220.9 & 3.10 & 2.95 & 3.03 & 54.03 & 64.06 & 59.05 \\
\hline & G.99-103 & 248.0 & 254.2 & 251.1 & 3.18 & 3.05 & 3.11 & 56.47 & 67.92 & 62.20 \\
\hline \multirow[t]{2}{*}{ Mean } & & 232.1 & 237.9 & 235.0 & 3.01 & 2.92 & 2.97 & 54.20 & 63.70 & 58.95 \\
\hline & Phil.8013 & 211.0 & 215.4 & 213.2 & 3.23 & 3.13 & 3.18 & 39.87 & 45.26 & 42.56 \\
\hline Mean for & G.T.54-9 & 236.8 & 243.2 & 240.0 & 2.77 & 2.67 & 2.72 & 44.62 & 51.61 & 48.12 \\
\hline \multirow[t]{2}{*}{ varieties } & G.98-28 & 208.1 & 218.9 & 213.5 & 3.12 & 3.01 & 3.07 & 43.35 & 51.14 & 47.24 \\
\hline & G.99-103 & 242.9 & 248.7 & 245.8 & 3.20 & 3.14 & 3.17 & 45.93 & 53.93 & 49.93 \\
\hline \multicolumn{2}{|c|}{ General mean } & 224.7 & 231.5 & 228.1 & 3.08 & 2.99 & 3.03 & 43.44 & 50.48 & 46.96 \\
\hline \multicolumn{11}{|c|}{ LSD at 0.05} \\
\hline \multirow{2}{*}{\multicolumn{2}{|c|}{$\begin{array}{c}\text { Row spacings (A) } \\
\text { Varieties (B) }\end{array}$}} & \multicolumn{3}{|c|}{2.2} & \multicolumn{3}{|c|}{0.04} & \multicolumn{3}{|c|}{0.46} \\
\hline & & \multicolumn{3}{|c|}{5.5} & \multicolumn{3}{|c|}{0.08} & \multicolumn{3}{|c|}{1.03} \\
\hline \multicolumn{2}{|c|}{ Seed rates $(\mathbf{C})$} & \multicolumn{3}{|c|}{1.2} & \multicolumn{3}{|c|}{0.02} & \multicolumn{3}{|c|}{0.62} \\
\hline \multicolumn{2}{|c|}{$\begin{array}{c}\text { Seed rates }(C) \\
A * B\end{array}$} & \multicolumn{3}{|c|}{9.5} & \multicolumn{3}{|c|}{ NS } & & NS & \\
\hline \multicolumn{2}{|c|}{$\begin{array}{l}A * B \\
A * C\end{array}$} & & NS & & & NS & & & 1.07 & \\
\hline B * & & & 3.3 & & & NS & & & 1.23 & \\
\hline$A * E$ & ${ }^{*}$ * $\mathrm{C}$ & & NS & & & 0.10 & & & NS & \\
\hline
\end{tabular}


The interaction between varieties and seeding rates with regard to number of millable stalks/fed was significant. It is clear that planting G.99-103 variety by using 12 -buds/ $\mathrm{m}$ gave the highest number of millable stalks (53.93 thousand/fed). The lowest value (39.87 thousand/fed) was obtained by planting Phil.8013 variety with 9-buds/fed.

\section{2- Quality parameters:}

2.1. Total soluble solids (brix \%)

Results in Table 2 cleared that inter-row spacings significantly affected brix values. Row spacing of $120 \mathrm{~cm}$ gave the highest brix value $(20.77 \%)$ whereas; $80 \mathrm{~cm}$ row spacing was recorded the lowest one $(19.85$ $\%$ ). These results are in line with that reported by Osman et al. (2004).

Brix values is greatly influenced by the different sugarcane varieties (Table2). Phil.8013 variety surpassed the other varieties, with an average of $21.52 \%$, while G.99-103 variety scored the lowest one with an average of $19.52 \%$. Differences among sugarcane varieties in brix values were also reported by Mohamed (1989) and Abdalla et al. (1995).

Table (2): Effect of row spacings, varieties and seed rates on TSS, Sucrose and reducing sugar percentages of plant cane crops during 2005/06 and 2006/07 (combined analysis of the two seasons).

\begin{tabular}{|c|c|c|c|c|c|c|c|c|c|c|}
\hline \multirow{2}{*}{$\begin{array}{c}\text { Row } \\
\text { spacings } \\
\text { (A) }\end{array}$} & \multirow{2}{*}{$\begin{array}{c}\text { Varieties } \\
\text { ( B ) }\end{array}$} & \multicolumn{3}{|c|}{$\begin{array}{c}\text { Brix \% } \\
\text { Seed rates ( C ) }\end{array}$} & \multicolumn{2}{|c|}{$\begin{array}{l}\text { Sucrose \% } \\
\text { Seed rates ( C ) }\end{array}$} & \multicolumn{4}{|c|}{$\begin{array}{l}\text { Reducing sugars \% } \\
\text { Seed rates ( C ) }\end{array}$} \\
\hline & & $\begin{array}{c}9- \\
\text { buds } / \mathrm{m}\end{array}$ & buds $/ \mathrm{m}$ & Mean & $\begin{array}{c}9- \\
\text { buds } / \mathrm{m}\end{array}$ & $\begin{array}{c}12- \\
\text { buds/m }\end{array}$ & Mean & $\begin{array}{c}9- \\
\text { buds } / \mathrm{m}\end{array}$ & $\begin{array}{c}12- \\
\text { buds/m }\end{array}$ & Mean \\
\hline \multirow{3}{*}{$120 \mathrm{~cm}$} & Phil.8013 & 21.83 & 21.55 & 21.69 & 18.60 & 17.92 & 18.26 & 0.26 & 0.27 & 0.26 \\
\hline & G.T.54-9 & 21.21 & 20.94 & 21.08 & 18.24 & 17.97 & 18.10 & 0.26 & 0.27 & 0.27 \\
\hline & G.98-28 & 20.49 & 20.24 & 20.36 & 17.18 & 16.86 & 17.02 & 0.24 & 0.27 & 0.25 \\
\hline \multirow{2}{*}{\multicolumn{2}{|c|}{$\begin{array}{l}\text { G.99- } \\
\text { Mean }\end{array}$}} & 20.03 & 19.85 & 19.94 & 16.25 & 15.67 & 15.96 & 0.26 & 0.28 & 0.27 \\
\hline & & 20.89 & 20.64 & 20.77 & 17.57 & 17.11 & 17.34 & 0.26 & 0.27 & 0.26 \\
\hline & Phil.8013 & 21.46 & 21.16 & 21.31 & 17.72 & 17.34 & 17.53 & 0.26 & 0.27 & 0.26 \\
\hline \multirow{2}{*}{$100 \mathrm{~cm}$} & G.T.54-9 & 20.93 & 20.43 & 20.68 & 17.76 & 16.90 & 17.33 & 0.27 & 0.28 & 0.27 \\
\hline & G.98-28 & 20.56 & 20.50 & 20.53 & 16.76 & 16.54 & 16.65 & 0.25 & 0.26 & 0.26 \\
\hline & G.99-103 & 19.89 & 19.98 & 19.93 & 16.13 & 16.05 & 16.09 & 0.27 & 0.27 & 0.27 \\
\hline \multicolumn{2}{|c|}{ Mean } & 20.71 & 20.52 & 20.61 & 17.09 & 16.71 & 16.90 & 0.26 & 0.27 & 0.27 \\
\hline \multirow{4}{*}{$80 \mathrm{~cm}$} & Phil.8013 & 20.80 & 20.70 & 20.75 & 17.13 & 16.90 & 17.01 & 0.26 & 0.27 & 0.27 \\
\hline & G.T.54-9 & 20.45 & 19.99 & 20.22 & 17.32 & 16.91 & 17.11 & 0.27 & 0.28 & 0.27 \\
\hline & G. $98-28$ & 19.88 & 19.66 & 19.77 & 16.29 & 15.80 & 16.04 & 0.26 & 0.27 & 0.26 \\
\hline & G.99-103 & 18.77 & 18.59 & 18.68 & 15.33 & 14.80 & 15.06 & 0.28 & 0.28 & 0.28 \\
\hline \multicolumn{2}{|c|}{ Mean } & 19.97 & 19.73 & 19.85 & 16.52 & 16.10 & 16.31 & 0.26 & 0.27 & 0.27 \\
\hline \multicolumn{2}{|r|}{ Phil.8013 } & 21.36 & 21.14 & 21.25 & 17.82 & 17.39 & 17.60 & 0.26 & 0.27 & 0.26 \\
\hline \multirow{2}{*}{$\begin{array}{l}\text { Mean tor } \\
\text { varieties }\end{array}$} & G.T.54-9 & 20.86 & 20.45 & 20.66 & 17.77 & 17.26 & 17.52 & 0.27 & 0.28 & 0.27 \\
\hline & G.98-28 & 20.31 & 20.13 & 20.22 & 16.74 & 16.40 & 16.57 & 0.25 & 0.26 & 0.26 \\
\hline \multirow{2}{*}{\multicolumn{2}{|c|}{$\begin{array}{l}\text { G.99-103 } \\
\text { General mean }\end{array}$}} & 19.56 & 19.47 & 19.52 & 15.90 & 15.51 & 15.71 & 0.27 & 0.28 & 0.27 \\
\hline & & 20.52 & 20.30 & 20.41 & 17.06 & 16.64 & 16.85 & 0.26 & 0.27 & 0.27 \\
\hline \multicolumn{11}{|c|}{ LSD at 0.05} \\
\hline \multirow{2}{*}{\multicolumn{2}{|c|}{$\begin{array}{c}\text { Row spacings (A) } \\
\text { Varieties (B) }\end{array}$}} & \multicolumn{3}{|c|}{0.32} & \multicolumn{3}{|c|}{0.40} & \multicolumn{3}{|c|}{ NS } \\
\hline & & \multirow{2}{*}{\multicolumn{3}{|c|}{$\begin{array}{l}0.55 \\
0.12\end{array}$}} & \multirow{2}{*}{\multicolumn{3}{|c|}{0.38}} & \multicolumn{3}{|c|}{ NS } \\
\hline \multicolumn{2}{|c|}{ Seed rates (C) } & & & & & & & \multicolumn{3}{|c|}{0.01} \\
\hline \multirow{2}{*}{\multicolumn{2}{|c|}{$A * B$}} & \multirow{2}{*}{\multicolumn{3}{|c|}{ NS }} & \multicolumn{3}{|c|}{ NS } & & NS & \\
\hline & & & NS & & & NS & & & NS & \\
\hline B & & & NS & & & NS & & & NS & \\
\hline$A *$ & ${ }^{*} \mathrm{C}$ & & NS & & & NS & & & NS & \\
\hline
\end{tabular}


Planting sugarcane with 9 -buds/m had significantly higher brix value compared to planting with 12 -buds $/ \mathrm{m}$. These results are in agreement with Mandloi et al. (1989).

All interactions were insignificant with respect to brix value.

\subsection{Sucrose \%:}

Data in Table 2 showed that sucrose\% was significantly affected by the tested row spacings. Sucrose \% decreased from 17.34 to $16.31 \%$ when row spacing decreased from 120 to $80 \mathrm{~cm}$. The increase of sucrose\% under the wider row spacing might be attributed to favorable growth conditioNS in terms of light interception and abundance of nutrients which increased photosynthesis activity and coNSequently more carbohydrates traNSlocated from leaves to the stalks. These results are in agreement with Mohamed and Ismail (2002) and Elwan (2007).

It is evident that varieties significantly differed in their sucrose content (Table2). It could be noticed that Phil.8013 variety produced the highest sucrose content (17.60\%), followed by the commercial varieties G.T.54-9, G.98-28 and G.103-99 variety in a descending order. These results are in line with those obtained by Ahmed et al. (2002) and Osman et al. (2004).

Results showed that decreasing rates of buds/m from 12 to 9 significantly increased sucrose \% from 16.64 to $17.06 \%$. This finding is in agreement with Mandloi et al. (1989). All interactions were insignificant with respect to sucrose \%.

\subsection{Reducing sugars \%:}

Results revealed that row spacings and varieties had no significant effect on reducing sugars \%. Results also showed that seed rates had a significant effect on reducing sugars \%. Increasing seed rate from 9 to 12 -buds/m significantly increased reducing sugars from 0.26 to $0.27 \%$. This result is in line with Saif etal (1999) who reported that increasing plant deNSity in terms of number of buds/fed.

\subsection{Purity \%}

Data in Table 3 revealed that purity \% was not significantly affected by row spacings; however there was a tendency for purity \% to increase with wider row spacing.

Data in the same table showed that sugarcane varieties differed significantly in purity percentage. It could be noticed that G.T.54-9 variety recorded the highest value of juice purity $(84.81 \%)$, followed by Phil.8013 (82.79\%), G.98-28 (81.93\%) and G.99-103 (80.54\%) in a descending order. Differences among sugarcane varieties in purity were reported by Mandloi et al. (1989) and Abd El-Azez (2008).

Seed rates significantly affected purity\%. Planting $9-$ buds $/ m$ gave the highest purity $(83.10 \%)$ as compared with 12 -buds $/ \mathrm{m}(81.94 \%)$. These results are in agreement with Azazy et al. (2003).

All interactions were not significant with respect to purity \%.

\subsection{Sugar recovery \%:}

The effect of row spacings on sugar recovery\% was significant (Table 3). It is clear that increasing row spacings from 80 to $120 \mathrm{~cm}$ significantly increased sugar recovery\% from 10.81 to $11.30 \%$, reflecting 
the higher sucrose content accompanying wider row spacing. These results are in stand in harmony with those obtained by Mohamed and Ismail (2002), and Osman et al. (2004).

Results also indicated that varieties exhibited significant differences in sugar recovery \% (Table3). It is clear that the highest value $(11.76 \%)$ was scored by G.T.54-9 variety, reflecting its highest purity \%, followed by Phil.8013, G.98-28 and G.99-103 variety in a descending order. It is worth to mention that difference between G.T.54-9 and Phil.8013 in sugar recovery \% was insignificant. These results are in harmony with those obtained by El-Geddawy et al. (1997).

Seed rates significantly affected sugar recovery \%. Planting 9buds $/ \mathrm{m}$ attained the greatest value of sugar recovery $(11.37 \%)$ as compared to 12 -buds $/ \mathrm{m}(11.03 \%)$. The higher sugar recovery with low plant deNSity might have been due to higher sucrose \% and purity $\%$ accompanying low plant deNSity is mentioned before. This result is in agreement with those obtained by Mandloi et al. (1989).

Table (3): Effect of row spacings, varieties and seed rates on purity and sugar recovery percentages of plant cane crops during 2005/06 and 2006/07 (combined analysis of the two seasons).

\begin{tabular}{|c|c|c|c|c|c|c|c|}
\hline $\begin{array}{c}\text { Row } \\
\text { spacings } \\
\text { (A) }\end{array}$ & $\begin{array}{c}\text { Varieties } \\
\text { ( B ) }\end{array}$ & $\begin{array}{l}\text { Seed } r c \\
\text { 9-buds } / \mathrm{m}\end{array}$ & $\begin{array}{l}\text { Purity\% } \\
\text { ates ( C ) } \\
\text { 12-buds/m }\end{array}$ & Mean & $\begin{array}{r}\text { Sug } \\
\text { Seed } r c \\
\text { 9-buds/m }\end{array}$ & $\begin{array}{l}\text { gar recovery } \\
\text { ates (C) } \\
\text { 12-buds/m }\end{array}$ & Mean \\
\hline \multirow{4}{*}{$120 \mathrm{~cm}$} & Phil.8013 & 85.03 & 83.15 & 84.09 & 12.52 & 11.99 & 12.25 \\
\hline & G.T.54-9 & 86.01 & 85.87 & 85.94 & 12.30 & 12.11 & 12.21 \\
\hline & G.28-98 & 83.86 & 83.21 & 83.54 & 11.50 & 11.24 & 11.37 \\
\hline & G.103-99 & 81.18 & 78.87 & 80.02 & 10.73 & 10.25 & 10.49 \\
\hline \multirow{4}{*}{$100 \mathrm{~cm}$} & ean & 84.02 & 82.78 & 83.40 & 11.76 & 11.40 & 11.58 \\
\hline & Phil.8013 & 82.59 & 81.98 & 82.29 & 11.82 & 11.51 & 11.67 \\
\hline & G.T.54-9 & 84.92 & 82.75 & 83.84 & 11.93 & 11.25 & 11.59 \\
\hline & G.28-98 & 81.49 & 80.62 & 81.05 & 11.12 & 10.92 & 11.02 \\
\hline & G.103-99 & 81.28 & 80.59 & 80.93 & 10.64 & 10.55 & 10.60 \\
\hline \multirow{5}{*}{$80 \mathrm{~cm}$} & ean & 82.57 & 81.49 & 82.03 & 11.38 & 11.06 & 11.22 \\
\hline & Phil.8013 & 82.35 & 81.67 & 82.01 & 11.40 & 11.22 & 11.31 \\
\hline & G.T.54-9 & 84.75 & 84.55 & 84.65 & 11.61 & 11.32 & 11.47 \\
\hline & G.28-98 & 82.03 & 80.36 & 81.19 & 10.80 & 10.39 & 10.59 \\
\hline & G.103-99 & 81.67 & 79.65 & 80.66 & 10.11 & 9.66 & 9.88 \\
\hline \multicolumn{2}{|c|}{ Mean } & 82.70 & 81.56 & 82.13 & 10.98 & 10.65 & 10.81 \\
\hline \multicolumn{2}{|c|}{ Phil.8013 } & 83.32 & 82.27 & 82.79 & 11.91 & 11.57 & 11.74 \\
\hline \multirow{2}{*}{$\begin{array}{l}\text { Mean for } \\
\text { varieties }\end{array}$} & G.T.54-9 & 85.23 & 84.39 & 84.81 & 11.95 & 11.56 & 11.76 \\
\hline & G.28-98 & 82.46 & 81.40 & 81.93 & 11.14 & 10.85 & 10.99 \\
\hline \multirow{2}{*}{\multicolumn{2}{|c|}{$\begin{array}{l}\text { G.103-99 } \\
\text { General mean }\end{array}$}} & 81.37 & 79.71 & 80.54 & 10.50 & 10.15 & 10.32 \\
\hline & & 83.10 & 81.94 & 82.52 & 11.37 & 11.03 & 11.20 \\
\hline \multicolumn{8}{|c|}{ LSD at 0.05} \\
\hline \multicolumn{2}{|c|}{ Row spacings (A) } & \multicolumn{3}{|c|}{ NS } & \multicolumn{3}{|c|}{0.52} \\
\hline \multicolumn{2}{|c|}{ Varieties (B) } & \multicolumn{3}{|c|}{1.80} & \multicolumn{3}{|c|}{0.42} \\
\hline \multicolumn{2}{|c|}{ Seed rates (C) } & \multicolumn{3}{|c|}{1.03} & \multicolumn{3}{|c|}{0.16} \\
\hline \multicolumn{2}{|c|}{$A * B$} & \multicolumn{3}{|c|}{ NS } & \multicolumn{3}{|c|}{ NS } \\
\hline \multicolumn{2}{|c|}{$A * C$} & \multicolumn{3}{|c|}{ NS } & \multicolumn{3}{|c|}{ NS } \\
\hline \multicolumn{2}{|c|}{$B * C$} & \multicolumn{3}{|c|}{ NS } & \multicolumn{3}{|c|}{ NS } \\
\hline \multicolumn{2}{|c|}{$A{ }^{*} B * C$} & & NS & & & NS & \\
\hline
\end{tabular}


3. Millable cane and recoverable sugar yields (ton/fed):

Results in Table 4 showed that row spacings differed significantly in their effect on millable cane yield and sugar yields (ton/fed). The highest millable cane yield (52.35 ton/fed) and sugar yield (5.40 ton/fed) were resulted from the middle row width $(100 \mathrm{~cm})$, while $120 \mathrm{~cm}$ row spacing scored the lowest values (46.57 and 5.35 ton/fed) for cane and sugar yields, respectively. It is worth to mention that the higher number of plant accompanying $80 \mathrm{~cm}$ row spacing could not compensate for the reduction in sucrose \% and sugar recovery \% and finally sugar yield was decreased. Also 80 and $120 \mathrm{~cm}$ row spacing were insignificantly different in sugar production per feddan. These results are supported by those obtained by El-Geddawy et al. (2002b).

Table (4): Effect of row spacings, varieties and seed rates on Millable and recoverable sugar yields of plant cane crops during 2005/06 and 2006/07 (combined analysis of the two seasons).

\begin{tabular}{|c|c|c|c|c|c|c|c|}
\hline \multirow{3}{*}{$\begin{array}{c}\text { Row } \\
\text { spacings (A) }\end{array}$} & \multirow{3}{*}{$\begin{array}{c}\text { Varieties } \\
\text { ( B ) }\end{array}$} & \multicolumn{3}{|c|}{ Millable cane yield (ton/fed) } & \multicolumn{3}{|c|}{$\begin{array}{c}\text { Recoverable sugar yield } \\
\text { (ton/fed) }\end{array}$} \\
\hline & & \multicolumn{2}{|c|}{ Seed rates ( C ) } & \multirow{2}{*}{ Mean } & \multicolumn{2}{|c|}{ Seed rates ( C ) } & \multirow{2}{*}{ Mean } \\
\hline & & 9-buds/m & 12-buds/m & & 9-buds/m & 12-buds/m & \\
\hline \multirow{4}{*}{$120 \mathrm{~cm}$} & Phil.8013 & 39.97 & 42.20 & 41.09 & 5.00 & 5.06 & 5.03 \\
\hline & G.T.54-9 & 44.77 & 46.23 & 45.50 & 5.51 & 5.60 & 5.56 \\
\hline & G.28-98 & 44.00 & 47.09 & 45.54 & 5.06 & 5.28 & 5.17 \\
\hline & G.103-99 & 52.73 & 55.54 & 54.13 & 5.64 & 5.65 & 5.64 \\
\hline \multicolumn{2}{|c|}{ Mean } & 45.37 & 47.76 & 46.57 & 5.30 & 5.40 & 5.35 \\
\hline \multirow{4}{*}{$100 \mathrm{~cm}$} & Phil.8013 & 47.87 & 49.76 & 48.81 & 5.66 & 5.71 & 5.69 \\
\hline & G.T.54-9 & 49.15 & 52.52 & 50.83 & 5.87 & 5.92 & 5.90 \\
\hline & G.28-98 & 49.79 & 53.15 & 51.47 & 5.54 & 5.82 & 5.68 \\
\hline & G.103-99 & 57.02 & 59.53 & 58.27 & 6.09 & 6.28 & 6.18 \\
\hline \multicolumn{2}{|c|}{ Mean } & 50.96 & 53.74 & 52.35 & 5.79 & 5.93 & 5.86 \\
\hline \multirow{4}{*}{$80 \mathrm{~cm}$} & Phil.8013 & 45.61 & 49.77 & 47.69 & 5.21 & 5.61 & 5.41 \\
\hline & G.T.54-9 & 46.47 & 49.73 & 48.10 & 5.41 & 5.64 & 5.52 \\
\hline & G.28-98 & 47.33 & 50.46 & 48.90 & 5.11 & 5.24 & 5.18 \\
\hline & G.103-99 & 53.31 & 57.60 & 55.46 & 5.39 & 5.56 & 5.47 \\
\hline \multicolumn{2}{|c|}{ Mean } & 48.18 & 51.89 & 50.04 & 5.28 & 5.51 & 5.40 \\
\hline \multicolumn{2}{|c|}{ Phil.8013 } & 44.49 & 47.24 & 45.86 & 5.29 & 5.46 & 5.38 \\
\hline Mean for & G.T.54-9 & 46.80 & 49.49 & 48.14 & 5.60 & 5.72 & 5.66 \\
\hline \multirow[t]{2}{*}{ varieties } & G.28-98 & 47.04 & 50.23 & 48.64 & 5.24 & 5.45 & 5.34 \\
\hline & G.103-99 & 54.35 & 57.56 & 55.95 & 5.71 & 5.83 & 5.77 \\
\hline \multicolumn{2}{|c|}{ General mean } & 48.17 & 51.13 & 49.65 & 5.46 & 5.61 & 5.54 \\
\hline \multicolumn{8}{|c|}{ LSD at 0.05} \\
\hline \multirow{2}{*}{\multicolumn{2}{|c|}{$\begin{array}{l}\text { Row spacing (A) } \\
\text { Varieties (B) }\end{array}$}} & \multicolumn{3}{|c|}{2.25} & \multicolumn{3}{|c|}{0.23} \\
\hline & & \multicolumn{3}{|c|}{2.28} & \multicolumn{3}{|c|}{0.31} \\
\hline \multicolumn{2}{|c|}{ Seed rates (C) } & \multicolumn{3}{|c|}{0.68} & \multicolumn{3}{|c|}{0.12} \\
\hline \multicolumn{2}{|c|}{$A * B$} & \multicolumn{3}{|c|}{ NS } & \multicolumn{3}{|c|}{ NS } \\
\hline \multicolumn{2}{|c|}{$A * C$} & & NS & & & NS & \\
\hline & & & NS & & & NS & \\
\hline$A *$ & ${ }^{*} \mathbf{C}$ & & NS & & & NS & \\
\hline
\end{tabular}

It is clear that varieties differed significantly in millable cane and sugar yields/fed (Table4). G 99-103 variety outyielded the other varieties in cane and sugar yields with an average of 55.95 ton/fed of millable cane and 5.77 toNS of sugar, while Phil.8013 variety was the lowest one in 
millable cane yield ( 45.86 toNS) and G.98-28 variety was the lowest one in sugar production with an average of 45.86 and 5.34 tons per feddan, respectively. The superiority of G.99-103 variety might have resulted from its superiority in number of millable stalks/fed as well as better growth characters in terms of length and diameter of stalks. Anjum (1991) and Javed (1994) reported differences in cane and sugar yields among varieties.

Increasing seed rates from 9 to 12 -buds/m significantly increased millable cane yield by $6.14 \%$ and sugar yield by $2.75 \%$. The increase in cane and sugar yields due to growing $12-\mathrm{buds} / \mathrm{m}$ is mainly due to the increase in number of millable cane/fed compared with 9-buds $/ \mathrm{m}$. The present results are in agreement with those obtained by Yadav (1993) and Azazy et al. (2003).

The higher cane yield 53.74 tons and sugar yield 5.93 tons resulted from cane planted on row $100 \mathrm{~cm}$ apart with 12 -buds $/ \mathrm{m}(48,000 \mathrm{buds} / \mathrm{fed})$.

\section{REFERENCES}

Abdalla, M.M.; R.A. Dawood; H. El-Hinawy and B. Dardir (1995). Effect of nitrogen fertilizer and date of harvest on sugarcane quality. Assiut $\mathrm{J}$. Agric. Sci., 26 (4): 49-57.

Abd El-Azez, Y.M. (2008). Evaluated some new sugarcane varieties as affected by harvesting dates under Middle and Upper Egypt conditioNS. M. Sc. Thesis, Fac. of Agric., El-Minia Univ. pp

Abd El-Latif, F.A.; Laila, M. Saif; Nour ELHoda, M. Taha and I.H. El-Geddawy (1993). RespoNSe of some sugarcane varieties to different levels of nitrogen. Egypt. J. Appl. Sci., 8 (11): 780-786.

Abo El-Ghait, R.A.M. (2000). Estimation of stability parameters for some sugarcane varieties. Ph. D. Thesis, Fac. of Agric., Minoufiya Univ.

Anjum, (1991). Ratooning potential of autumn sugarcane as affected by pits and flat planting. M. Sc. (HoNS). Thesis, Dept. Agron. Univ. Agric., Faisalabad, Pakistane.(C.F. computer search).

A.O.A.C. (1995): Association of Official Analytical Chemists. Official methods of analysis, $16^{\text {th }} \mathrm{Ed}$. AOAC International, Washington, D.C., USA.

Avtar-Singh and R. Singh (2001). Effect of agronomic practices on the productivity of late planted sugarcane. Crop-Research-Hisar, 21(2): 123-125.

Azazy, N.B.; A.M.A. EL-Shafai and A.I. Nafei (2003). Effect of row spacing and seeding rate on some sugarcane varieties. Egypt. J. Appl. Sci.; 18(IIB) .

Chang, J.H. (1974). Radiation balance. Climate and agriculture. Aldine publishing Co., Chicago, Illinois:4-22. (C.F. computer search).

Dominf, M.E. and R. Plana (1989). Effect of planting deNSity on growth and production of setts in sugarcane (Saccharum sp.). Cultivos Tropicales, 11(3):67-73. INSt. Nacional de Ciencias Agricolas, Havana, Cuba. [C.F. Field Crop Abst., 1991, 44(5):3373]. 
El-Geddawy, I.H.; D.G Darweish,.; A.A. El-Sherbiny,; and E.E.A. El-Hady (2002a). Effect of row spacing and number of buds/seed setts on yield component of ratoon crops for some sugarcane varieties ratoon. Pakistan Sugar J., 17(1): 24-28.

El-Geddawy, I.H.; D.G Darweish,.; A.A. El-Sherbiny,; and E.E.A. El-Hady (2002b). Effect of row spacing and number of bud/seed setts on juice quality of ratoon crops for some sugarcane varieties. Pakistan Sugar J., 17(4): 10-17.

El-Geddawy, I.H.; A. S. El-Debaby; A. M. M. Saad and N.B. Azzazy (1997). Irrigation systems and nitrogen fertilizer in relation to yield and quality of sugarcane varieties. Egypt. J. of Agric. Res., 75 (4): 1037-1053.

El-Geddawy, I. H.; S.E. Shafshak,; G.Y.M. Hammam, and A.M.A. El-Shafai, (2004). Irrigation regimes and nitrogen fertilization effect on sugarcane yield and its components. Egyptian Journal of Agricultural Research. 82(4): 1721-1732.

El-Gergawy, A.S.; A. Mokadem; M.A. Salem; and T.S. El-Amary (1995). Effect of rates of seed cutting and dates of harvesting on yield and quality of the released sugarcane variety G.85/37. Egypt. J. Appl. Sci.; 10(6):848-854.

El-Sayed, G. S. (1996). Effect of plant population deNSity and nitrogen fertilization on the yield and quality for some sugarcane varieties. M.Sc. Thesis, Fac. of Agric., Moshtohor, Zagazig. Univ.

EL-Shafai, A.M.A. (1996). Water requirements of sugarcane under different levels of nitrogen fertilization. Ph.D. Thesis, Agron. Dept. Fac. of Agric. Moshtohor, Zagazig Univ.

El-Sogheir, K.S. and H. Ferweez (2009). Optimum harvesting age of some promising sugarcane genotypes grown under different nitrogen fertilizer levels. Egypt. J. Appl. Sci., 24(3):195-214.

El-Sogheir, K.S. and A.M. Mohamed (2003). Optimal seed rate for some promising sugarcane varieties. Egypt. J. Agric. Res. 81 (4): 1693-1705.

Elwan, A.M. (2007). Effect of nitrogen levels and row spacing on growth, yield and quality of some sugarcane varieties in Middle and Upper Egypt. Ph.D. Thesis. Agron. Dept., Fac. Agric., Al-Azhar Univ. pp 168.

Gomez, K.A. and A.A. Gomez (1984): Statistical procedures for agricultural Research, Second Edition. John Willey and SoNS, New York, pp.680.

Ismael, F.M.; S. Seeruttun,; C. Barbe, and A. Gaungoo (2007). Improving cane productivity with dual row planting in Mauritius. XXVI-Congress,International-Society-of-Sugar-Cane-Technologists,-ICC,-Durban,South-Africa,-29-July-2-August,-2007. 2007; 220-228.

Javed, M.S. (1994). A study on comparative rationing performance of some sugarcane varieties. M. Sc. (HoNS). Thesis, Dept. Agron. Univ. Agric., Faisalabad, Pakistane.

Mandloi, K.S.; R.V. Singh and B.R Lokhande (1989). RespoNSe of sugarcane varieties to row spacing and seed rate. Indian J. Agron., 34(2):247-249. Mohamed, B.D. (1989). Effect of nitrogen fertilizer and harvest time on yield and quality of sugarcane. M.Sci. Thesis, Fac. Agric., Assiut. Univ., Egypt. 
Mohamed, B.D. and A.M.A. Ismail (2002). Influence of planting seasoNS and nitrogen fertilizer levels on productivity of three sugarcane varieties. Egypt. J. Appl. Sci., 17(3):64-77.

Mokadem, S. A.; E. M. Taha; I. H. El-Geddawy and M. A. Bekheet (2000). RespoNSe of spring sugar-cane to some row spacing and intercropping with sorghum and soybean. Egypt. J. Agric. Res. 78(1): 197-214.

Nafei, A.I. (1993). Effect of some agricultural treatments on yield and quality of sugarcane. M..Sc. Thesis, Fac. Of Agric, Al-Azhar Univ., Cairo.

Osman, A.M.H.; G.S. El-Sayed and A.I. Nafei. (2004).Effect of row spacing and ploughing on yield and quality of some sugarcane varieties. Egypt. J. Appl. Sci.; 19(2)

Rizk, T.Y.; M.H. El-Agroudy; I.H. El-Gedawy; and M.A. Fergany (2004). Effect of row distance and cutting size on growth criteria of tow promising sugarcane varieties and the commercial variety. Egypt. J. Agric. Res., 82(1):263-276.

Saif, L.M.; Nour EL-Hoda, M. Taha and Moona, M. Shehata (1999). Effect of plant deNSity and nitrogen fertilizer on yield and quality of sugarcane varieties. Egypt. J. Appl. Sci.; 14(11).

Satisha, G.C. ; M. Krishnappa and K. Srikanth (1996): Input of sulphur on yield and quality of sugarcane . Indian Sugar 45( 9): 397-401

Shah-Nawaz, V.; A. Riaz; Abdul-Jabbar; M. Tariq and A. Ashfaq (2000). Biological traits of autumn sugarcane as influenced by spatial arrangement and plantation method. Dept. Agron., Fac. of Agric., Univ. of Faisalabad, Pakistan. Pakistan Sugar J., 15 (5): 15-19.

Singh, R.K. and G.P. Singh (1998). Effect of sampling time on efficiency of selection for quality traits in sugarcane. Sugarcane (3):13-17.

SteveNSon ,G.C.( 1965): Genetics and breeding of sugarcane. Book , printed by Buler \& Tanner LTD, London .

Sukhchain, A. K. and S. R. Saini (1998). Effect of waterlogging and high water table on vatiet al. performance in sugarcane. Sugarcane. (1): 1516.

Tej-Pratap; Ranjeet-Singh and P.P. Singh (2006). Studies on the effect of row-spacing, seed rate and fertility levels on quality and yield of sugarcane (Saccharum officinarum). Indian-sugar. 2006; 56(2):21-24.

Usman, B. (1989). Influence of AS dosage addition and amount of cane cuttings on plant growth, NPK leaf content and yield of several cane varieties. Majalah Perusahaan Gula, 25(1):1-12. (C. F. Computer search).

Yadav, R.L. (1993). Cane yield in relation to shoot-population deNSity of sugarcane (Saccharum species). Indian J. Agron., 38(2):337-338.

Yadav, R.L. and R.K. Sharma (1980). Effect of nitrogen levels and harvesting dates on quality characters and yield of four sugarcane genotypes. Indian J. of Agric. Sci. 50(7):581-589.

Yousef, M.A.; E.M. Taha, and Z.A. Ahmed (2000). Influence of some cultural practices on yield and yield components of some sugarcane varieties. Egypt. J. Agric. Res., 78(5) 20-27. 
Mahmoud, E.A. et al.

سلوك بعض أصناف القصب الواعدة تحت مستويات مختلفة من الكثافة النباتيـة

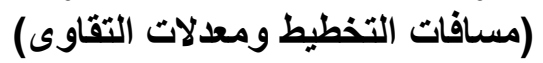

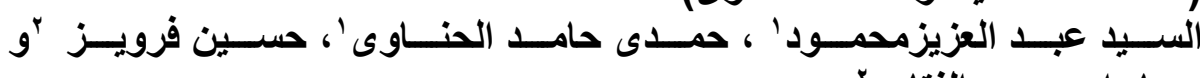

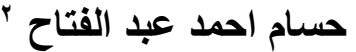

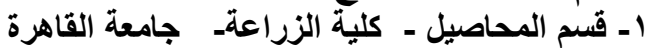

r- معهز بحوث المحاصيل السكرية ، مركز البحوث الزية الزراعية ،جمهورية مصر العربية

من المهز تحديد الكثافة النباتية المثلي التى عندها يعطى صنف قصب السكر اقصى إنتاج من السكر

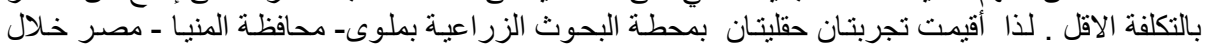

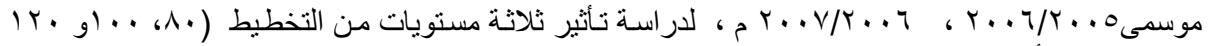

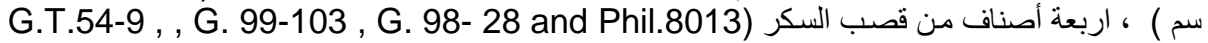
) مستويين من كمية التقاوى( 9 براعم و و با بر اعم / م طولى ) في تصميم قطع منشقة مرتين على الصفات

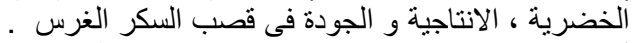

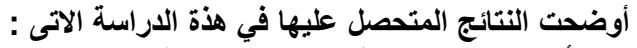

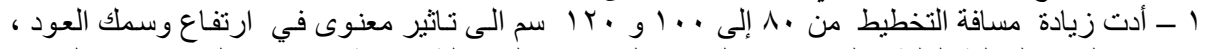

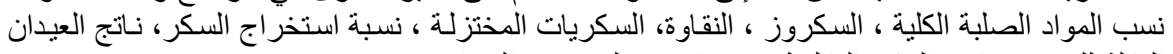

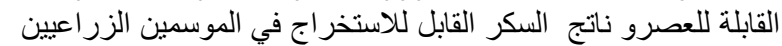

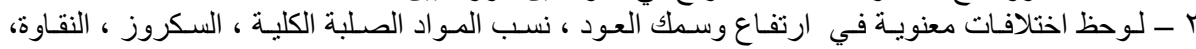

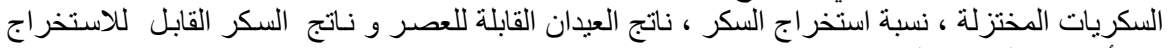

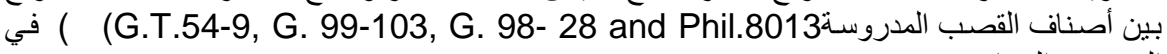

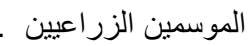

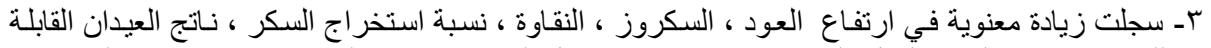

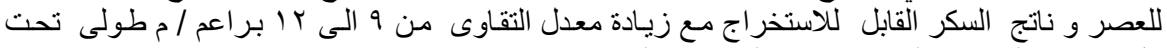

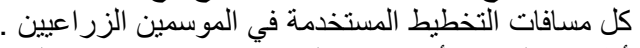

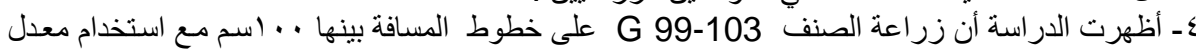

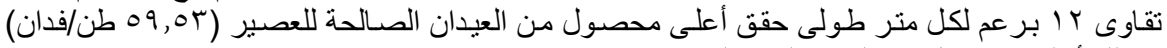

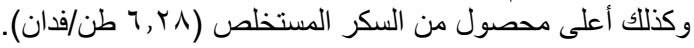

